\title{
THE SOCIAL WELL-BEING ISSUES OF THE EUROPEAN URBANISATION STAGES AND THE POSSIBILITIES OF THEIR MANAGEMENT BY THE CREATION OF SPATIAL CONFIGURATIONS ${ }^{1}$
}

Viktória SZIRMAI, University Professor, Head of Department Kodolányi János University of Applied Sciences

Research Professor at the Institute for Sociology, Centre for Social Sciences, Hungarian Academy of Sciences

Address: $\quad 1014$ Budapest, Országház u. 30

Phone: +36-1/224-6742 (412)

E-mail: $\quad$ Szirmai.Viktoria@tk.mta.hu

\footnotetext{
${ }^{1}$ The lecture that this study is based on was presented at the 11th Regional Assembly of the Hungarian Regional Scientific Association in Kaposvár on 21-22 november, 2013 in Session 4, titled 'The New European Cohesion Policy and its Prospective Effects, The Development of Urban regions'.
} 
Szirmai, V.

\title{
THE SOCIAL WELL-BEING ISSUES OF THE EUROPEAN \\ URBANISATION STAGES AND THE POSSIBILITIES OF THEIR \\ MANAGEMENT BY THE CREATION OF SPATIAL \\ CONFIGURATIONS
}

Key words: Social wellbeing, European urbanisation, Social tension, Social configuration

\begin{abstract}
Cities today play strategic roles in modernization processes as well as in the organization and operation of global economy. Big cities are the places where the conditions of modernisation, economic and social development, the operating conditions of global economy, the educated and qualified middle-class, members of the economic, political and cultural elite are concentrated. Meanwhile modern urban spaces are rather controversial. A variety of social problems, the traditional and new structures of local social inequalities, the historical and present day poverty, traditional and modern crime, environmental problems are all present.

Various urban problems were also present in the historically changing stages of urban development. Taking the actual historical and social conditions into account, theories, criticisms, and various scientific approaches offered differentiated solutions - mainly based on spatial principals - to manage urban tensions. As urban conflicts keep reproducing and new tensions keep appearing these tools do not seem to succeed in managing these tensions, which is probably due to the one-dimensional aims of intervention. Management proposals regarding particular urbanisation stages were mainly based on spatial principals, they were one-dimensional, and they were not accompanied with schemes targeting structural effects.

The aims of this study to present the various urban problems connected to the different urbanisation stages, as well as the proposals based on spatial principles which were aspiring to solve these problems and to evaluate these proposals. A further aim is to describe a complex structural management theory, which is very promising from the aspect of structural effects but lack the spatial approach. Finally this study aims to present a research whose aspiration is to connect the two different approaches empirically.
\end{abstract}

Kulcsszavak: Társadalmi jól-lét, európai urbanizáció, társadalmi feszültségek, társadalmi szerkezet

\begin{abstract}
Absztrakt:
Napjaink városai kiemelt szerepet játsznak a modernizációs folyamatokban, valamint a globális gazdaság szervezésében és működtetésében. A nagyvárosokban koncentrálódik a modernizáció, a gazdasági és társadalmi fejlődés, a globális gazdaság müködésének feltételei, az iskolázott és magasan kvalifikált középosztály, illetve a gazdasági, politikai és kulturális elit tagjai. Mindeközben a modern városi terek ugyanakkor ellentmondásokkal is terheltek. A társadalmi problémák széles köre, a helyi társadalmi egyenlötlenségek hagyományos és újfajta struktúrái, a történelmi és a mai szegénység, a bünözés hagyományos és modern formái, valamint a környezeti problémák egyaránt jelen vannak.

A városfejlődés történetileg változó szakaszait ugyancsak különböző városi problémák jellemezték. Az aktuális történelmi és társadalmi feltételeket figyelembe véve az egyes elméletek, kritikák és a különbözö tudományos megközelítések - föként térbeli szabályszerüségekre alapozva - eltérő megoldásokat javasoltak a városi feszültségek kezelésére. Mivel a városi konfliktusok folyamatosan újratermelődnek és emellett újabb feszültségek is megjelennek, ezek az eszközök nem bizonyultak sikeresnek a feszültségek kezelésében, vélhetően a beavatkozások túlságosan egydimenziós céljainak köszönhetöen. Az egyes urbanizációs szakaszok esetében kidolgozott kezelési javaslatok tehát föként a térbeli szabályszerüségeken alapultak és egydimenziósak voltak, továbbá nem tartalmaztak a strukturális hatásokkal foglalkozó elemeket.

A tanulmány célja az egyes városfejlődési szakaszokhoz kapcsolódó városi problémák bemutatása, valamint az ezek megoldását célzó - térbeli szabályszerüségek alapján megfogalmazott - javaslatok ismertetése és értékelése. A munka további célja egy komplex strukturális kezelési elmélet bemutatása, amely a strukturális hatások tekintetében rendkívül ígéretes, ugyanakkor nem térbeli szempontú. Végezetül, a tanulmány egy olyan kutatást is ismertet, amely empirikus módon igyekszik kapcsolatot teremteni a kétféle megközelítés között.
\end{abstract}




\section{INTRODUCTION}

The 21 st century is the century of the city. Today nearly $50 \%$ of the world's population lives in urban spaces and this proportion is gradually increasing. Cities today play strategic roles in modernization processes as well as in the organization and operation of global economy. Big cities are the places where the conditions of modernisation, economic and social development, the operating conditions of global economy, the historically accumulated knowledge, the cultural heritage, architectural works, services providing wellbeing and comfort, the latest infrastructures, the social groups that created them and make use of them, the educated and qualified middle-class, members of the economic, political and cultural elite are concentrated. Meanwhile modern urban spaces are rather controversial. A variety of social problems, the traditional and new structures of local social inequalities, the historical and present day poverty, traditional and modern crime, environmental problems, the most diverse forms of social conflicts, and most recently terrorist acts and the hazards of global climate change are all present.

Various urban problems were also present in the historically changing stages of urban development. Taking the actual historical and social conditions into account, theories, criticisms, and various scientific approaches offered differentiated solutions - mainly based on spatial principals - to manage urban tensions. As urban conflicts keep reproducing and new tensions keep appearing these tools do not seem to succeed in managing these tensions, which is probably due to the one-dimensional aims of intervention. Management proposals regarding particular urbanisation stages were mainly based on spatial principals, they were one-dimensional, and they were not accompanied with schemes targeting structural effects.

Recently, however, several more complex problem management theories, based on mainly structural elements, have appeared to handle their predecessors' failure. It is favourable from the sociological perspective. On the other hand, it may also be criticized, as spatial principles regarding structural intervention; the methods of problem management are not elaborated. It is due to the fact that the interconnecting systems of structural and spatial principles - the questions what spatial environment and what spatial features result in the positive effects of structural mechanisms - have not been examined yet.

This study naturally cannot undertake this task, but it aims to present the various urban problems connected to the different urbanisation stages, as well as the proposals based on spatial principles which were aspiring to solve these problems and to evaluate these 
proposals. A further aim is to describe a complex structural management theory, which is very promising from the aspect of structural effects but lack the spatial approach. Finally this study aims to present a research whose aspiration is to connect the two different approaches on empirical basis. ${ }^{2}$

\section{THE SOCIAL TENSIONS OF THE MAIN STAGES OF GLOBAL URBANISATION}

Modern urbanisation is a cyclic process that prevails in certain areas (countries, regions, settlements), it is determined by actual social, economic and historical factors, and centralization and decentralization processes follow each other. The evolution of modern urbanization cycles are greatly determined by long-term economic cycles. (Enyedi, 2011)

The first stage was the extensive economic development generated urban explosion, when the urban concentration of the population became characteristic. New urban forms of historically unprecedented size and characteristics came into being: large cities, metropolises, megapolises, which can be defined as adjoining chains or conglomerations of several large cities.

This process co-existed with the crisis of traditional settlements forms and ways of living, the disintegration of village communities and the extinction of traditional ways of living. In the early stage of urbanisation, in the stage of rapid urban growth, several negative phenomena appeared including the loosening and marginalization of the once so important family-, kinship- and neighbourhood-ties that characterised village communities. People became individualised and were left without representative models of lifestyle and relationships. Various forms of deviant behaviour appeared, crime, prostitution, alcoholism also became characteristic. Individual isolation also led to an increase in the number of suicides. Poverty, housing problems affected more and more people. As opposed to the apparently idyllic village communities, the social image of the sinful city emerged. As a result several intellectuals, researchers, among them architects sensitive to social problems

\footnotetext{
2 The publication was co-financed by the EU and the European Social Fund. It is prepared in the framework of TÁMOP-4.2.2.A-11/1/KONV-2012-0069 project titled: 'Social Conflicts - Social Well-being and Security- Competitiveness and Social development'. The project and the founding research is carried out in the framework of a consortium led by Kodolányi János University of Applied Sciences and with the participation of Széchenyi University, Györ, the Economic and Regional Academic Research Centre, Regional Research Institute of HAS between 2013 and 2015. The project leader is Viktória Szirmai.
} 
began to search for the solution for this issue. Two remarkable concepts are worth for presentation here.

One of them sought to resolve the problems of existing cities, including the housing problems of working class people by building a different kind of city which is better planned, modernized, and provides sunshine and clean air and favourable living conditions for every inhabitant alike. It was Le Corbusier's functionally planned city concept, elaborated in the 1920s. (Le Corbusier, 1923) Ebenezer Howard suggested something different: seeing the problems cities are facing, he rejected the city and announced the idea of the garden city. According to his plans garden cities, which are built in the peripheries of large cities but are separated from them, provide their inhabitants - as compact settlements - with housing, workplaces and facilities for spending free-time. Meanwhile garden cities socially integrate local residents and simultaneously offer the opportunities of both rural and urban forms of living. (Howard, 1902)

Howard's garden city plans were only realised in a few cases, but their effects appeared in various urban planning concepts. Paradoxically, the achievements of the garden city movement are represented by the protection of existing cities rather than their rejection. Satellite towns, new towns, suburban towns were later built in the peripheries of several European cities in order to prevent extreme urban sprawl and to control and direct residential migration. Another aim was to provide people who want to get away from big cities with calm and peaceful residential environment. The relevance of the garden city concept, the realisation of plans, that is the formation of spatial communities offering the unity of residence and workplace, and their long-term sustainability were overruled by several factors in Europe: economy was transformed by new processes, the dynamic development of the service industry attracted masses of people to urban areas and last but not least the requirements regarding life style and life style forms changed, their local nature diminished and later globalisation trends appeared.

The large-scale housing shortage after World War II resulted in very serious social problems. These problems were even more serious than those described by Engels in the mid-1800s (Engels, 1845) as they caused difficulty not only in terms of quality but in terms of quantity, as well. The housing shortage was made even worse by the great wave of immigration - which affected Europe as well - from former colonies to mother countries and which was also connected with poverty issues. In order to spatially manage this problem several European capital cities decided to create huge housing estates in the outskirts with blocks of flats built from prefabricated, standardised units. The housing 
estates were also meant to influence lifestyle and to function as the framework of community relations. These goals, however, failed, they could not even have succeeded since local ways of living only partly depend on the built environment, rather they are shaped by social structural specificities.

In the first periods these housing estates offered housing for lower middle-class people, but due to the deficiencies of infrastructure and the monotonous built environment a lot of residents became dissatisfied and wanted to move or actually moved out of these homes. This led to the transformation of the social composition of housing estates in all the affected European cities. They have become one of the characteristic forms of segregation organised from lower social status population or immigrants.

The situation is basically similar in the case of new towns which evolved around large European capital cities, but it is also similar in the case of post-socialist industrial new towns. The society of new towns, which were originally built for middle-class people dissatisfied with urban problems, has also changed.

The second stage of urbanisation is the intensive phase of economic development involving the relative spatial deconcentration of the population. Deconcentration primarily affects large cities: this is the period when agglomerations are formed, suburbanisation processes become more dynamic, the proportion of urban population and the significance of urban economy continue to grow. (Enyedi, 2012) Other units of the settlement network such as small and medium-sized towns and certain villages begin to develop as well.

This is the period of the crisis of Fordism as a peculiar form of business organisation, where raw materials are processed on the same location as manufacturing takes place, and which form was also characterised by several features: "geographic concentration tendency, agglomeration benefits deriving from the spatial proximity of big companies, economic zones created by the combination of the source of raw materials, masses of labour force, the large consumer market and of transport routes and urban growth, especially the growth of large cities". (Enyedi, 1996, p. 24)

The difficulties of this era were increased by the fact that well-being state models, developed in the framework of a general modernisation tendency after World War II, fell into a deep crisis after the oil crisis of the 1970s and then of the 1980s (and later following the globalisation challenges of the 1990s). The weaker advocacy chances of national states, as compared to global forces, the financial difficulties of the economic and social crisis made the well-being models incapable of protecting the relatively balanced social features such as low unemployment, well-being innovations, the dynamism of local social 
networks, the relative spatial-social integration which were so characteristic of Fordist cities.

In the third stage of urbanisation the intensification of deconcentration processes can be observed. This is the period of Post-Fordism when new processes, earlier not characteristic of big cities, appear: the decay of the nuclear family, the decay of local communities, individualisation. Further characteristics of this stage also include long-term unemployment, urban poverty, social conflicts arising from the mass migration of unskilled (Asian, Africa) workers to European cities, social segregation, the tensions of the credit crisis affected indebted middle-class of the early 2000s.

All these indicate the deep crisis of urban social life, which is also shown by the decrease of urban population. An increasingly significant part of the middle-class living in large cities leaves the inner districts - which are full of social problems, transport difficulties, and which districts obviously concentrate urban poverty - and move to suburban cities or to peri-urban settlements.

This stage of urbanisation is accompanied by the organisation of specific spatial configurations. These are the garden city quarters located in the outskirts of the city or the independent peri-urban settlements, where due to urban sprawl, local society is replaced and becoming mainly more middle-class. They may also include the new segregation areas of peri-urban middle and upper middle-class population, the gated communities protected by security guards and cameras.

Urban sprawl and its spatial configurations bring forth special social problems: due to the increase of motorisation natural environment is seriously harmed, environmental damage, the permanent commuting ruin the general health of the affected population as well. Significant social conflicts develop between city centres and suburbs but also between peri-urban settlements. (Szirmai, 2011) These new configurations are unable to manage the social problems of large cities, as those problems prevail or they may affect different social groups (those who stayed, or those who replaced the original inhabitants).

The fourth stage of urbanisation is the globalised urbanisation. It means newer concentration processes, repeated demographic explosion. The main processes of global economy, the full development of world capitalism are expressed by this stage (Enyedi, 2012). It also means that global effects appear everywhere in the world, even in the places where the former three stages also prevail. But the sequential order of the stages, the process of geographic spread already changed, became specific. 
The development of global economy and the resulting global economic integration along with the acceleration of urban development also created new types of urban spaces, complex urban systems (Hall, 1966, Castells - Godard, 1974, Friedmann - Wolff, 1982). It is important to highlight the strong metropolitan concentration of global capital and its institutions (Sassen, 1991). Castells called them the uniquely new urbanisation forms of our time (Castells, 1974). Ascher also agrees that the multi-functional metropolises which are strongly integrated into international economy are completely new "types of space". The connections that metropolises establish with their own surroundings, with the country, with other cities are different from the connections that were characteristic of industrial cities and of regional large cities of the previous historical periods. (Ascher, 1995)

In this stage the rehabilitation of large city-centres becomes important for the global capital and its representatives and this manages the crisis of inner cities, significantly slows down the out-migration from city centres, and as a result the increase of the number of inner city residents can be observed.

Distinctive regional inequalities, more prominent social polarisation characterise the social-spatial structure organised in the global urbanisation stage. Wealth and upper classes concentrate in city centres and in good suburbs, whereas lower social classes concentrate partly in city centres and partly in urban peripheries.

In European cities disadvantegous inhabitants are driven out to the outskirt areas; in American city centres the inner city concentration of the poor was historically characteristic, today, however, it seems to be changing as well: the social status of inner districts rose according to the already ultra-urban interests of the global elite (Sassen, 1991).

Globalisation not only created intense social polarisation, huge differences between the poor and the rich, but it also resulted in fierce competition between cities (and city districts) for investment, employees, consumption and the purchasing power of the middle-class. In this period the increase of spatial polarisation is more and more obvious, city areas that conform to the criteria of global competition and areas that do not (stigmatised city areas) are revealed. 


\section{A FROM TERRITORIAL TO STRUCTURAL APPROACHES TO MANAGE URBAN ISSUES}

Several kinds of scientific theories were created to interpret the social problems of urban cycles. Among them the work of the "Chicago School", which appeared at the beginning of the 1920 s, is especially important. According to the so called human ecological theory elaborated by the school, the spatial-social structure, the ecological units or natural zones are the most significant factors determining urban social phenomena, the neurotic phenomena of the city and the disintegration of human relationships, but also the prospective social integration processes. (Park - Burgess - Mckenzie, 1925) This theory was not only significant because it was the leading theory in researches on urban societies, but it was also important because it provided the basis for the interpretation of social problems as well as problem management methods according to spatial principles.

However, in the 1960s the research direction that was exclusively based on spatial principles, more exactly on human ecological explanation, was severely criticised. Gans was the first to draw the general conclusion that when interpreting the various life forms existing in a city, one must consider the social-occupational stratification instead of the ecological relations (Gans, 1962). Castells claimed that the ecological determination of the Chicago School is outdated, since the ecological approach did not take into account that the structure, the usage, and physical quality of space are the outcome of the activities of various social groups (Castells, 1972).

Since the 1970s several new urban issues have appeared which the human ecological theory cannot explain, neither can it offer theoretical grounds for different city-policy interventions. According to Kleniewski such problems include the declining number of city centre inhabitants, the strengthening of social polarisation, economic instability, increasing differences between cities, which are actually the tensions of the third and mainly of the fourth (global urbanisation) stages of urbanisation (Kleniewski, 2005, Sassen, 2007).

Several serious works were written to analyse the tensions of the global urbanisation stage from a structural approach. Among them Saskia Sassen's works, including the study „Urban Sociology of the 21st Century” is especially important. (Sassen, 2007) In this work Sassen presents and analyses cities, urban issues from a global economic and trans-national urban system perspective; as well as their social polarisation effects, the contradictions 
between global capital and different disadvantageous social groups (immigrants, women) that are simultaneously present in urban spaces (Sassen, 2007).

\section{A NEW POSSIBILITY TO STRUCTURALLY MANAGE URBAN SOCIAL ISSUES}

The theory elaborated by Stiglitz's report may offer a comprehensive means to manage social problems, including social problems in large cities. The study titled „Report by the Commission on the Measurement of Economic Performance and Social Progress" was compiled in 2009 with the leadership of Joseph Stiglitz. Members of the Commission were internationally acknowledged and recognised economists and sociologists. The report was written on the request of the President of the French Republic, Nicholas Sarkozy, in order to examine the main determining factors of the current economic, financial and social crisis, the limitations regarding GDP calculations. The examination was based on the hypothesis that the GDP, as an indicator to measure social and economic processes, is not able to measure social progress. Analyses which justified the document ascertained that the GDP is not the appropriate means to measure the development of social processes (in other words to measure social well-being), and thus new tools of measurement are needed, tools that include the aspects of sustainable development and its three main pillars economic, environmental and social relationships as well. The report clearly verified that the focus must be shifted from production- and economy-oriented measurement to the social wellbeing of contemporary and future generations. It must be done so that the unfavourable social tensions of the economically-oriented urban planning models, which disregard social aspects, could be managed.

The theoretical significance of the social progress model based on the Stiglitz Report is outstanding as it offers a complex and novel solution to manage current world economic problems, it provides new opportunities for social integration and progress while revitalising economy, but instead of focusing on production it focuses on the well-being of the examined countries and regions.

The social development model based on the Stiglitz Report is only a theory today, we still lack a complex model which is based on actual empirical facts revealing the connections of economic and social development and social well-being on European, national and worldwide level; there are only analyses that concentrate on certain connections of social well-being, that is we only have partial results. 
Szirmai, V.

That is why we undertook to carry out a research (in the framework of a 5000-person representative sociological research) that aims to reveal the well-being levels of the different spatial-social groups of the 9 large Hungarian metropolitan regions considering the indicators of the Stiglitz Report. Next we will link the empirically revealed, spatially and socially differentiated well-being indicators to the various social problems and their levels, which are characteristic of the 9 large Hungarian metropolitan regions. This way we will analyse the spatial background of social well-being which depends on structural aspects, the complex determination of urban social problems. ${ }^{3}$

\section{CONCLUSIONS}

Recent article aimed to present the different social tensions of the main stages of global urbanisation process, furthermore, evaluated certain proposed solutions based on altering territorial approaches. Though, after historical analyses of the stages of global urbanisation, they were hardly able to manage important social issues. Theoretically the well-being concept elaborated by the Stiglitz report offers a more adequate opportunity to solve diversified serious social tensions. The first empirical results of a representative survey $(\mathrm{N}=5.000)$ carried out in the nine large Hungarian metropolitan areas demonstrated the urgent necessity of complex interventions, the simultaneous applications of territorial and structural management tools.

\section{SUMMARY}

The 21 st century is the century of the city. Today nearly $50 \%$ of the world's population lives in urban spaces and this proportion is gradually increasing. Cities today play strategic roles in modernization processes as well as in the organization and operation of global economy. Big cities are the places where the conditions of modernisation, economic and social development, the operating conditions of global economy, the historically accumulated knowledge, the cultural heritage, architectural works, services providing well-being and comfort, the latest infrastructures, the social groups that created them and make use of them, the educated and qualified middle-class, members of the economic, political and cultural elite are concentrated. Meanwhile modern urban spaces are rather controversial. A variety of social problems, the traditional and new structures of local social inequalities, the historical and present day poverty, traditional and modern crime, environmental problems, the most diverse forms of social conflicts, and most recently terrorist acts and the hazards of global climate change are all present.

Various urban problems were also present in the historically changing stages of urban development. Taking the actual historical and social conditions into account, theories, criticisms, and various scientific approaches offered differentiated solutions - mainly based on spatial principals - to manage urban tensions. As urban conflicts keep reproducing and new tensions keep appearing these tools do not seem to succeed in managing

\footnotetext{
${ }^{3}$ The presentation of these findings will be the subject of another study, as data collection (carried out by TÁRKI Social Rechearch Intitute) will only have been finished by March 2014, analyses will be done subsequently.
} 
these tensions, which is probably due to the one-dimensional aims of intervention. Management proposals regarding particular urbanisation stages were mainly based on spatial principals, they were one-dimensional, and they were not accompanied with schemes targeting structural effects.

The aims of this study to present the various urban problems connected to the different urbanisation stages, as well as the proposals based on spatial principles which were aspiring to solve these problems and to evaluate these proposals. A further aim is to describe a complex structural management theory, which is very promising from the aspect of structural effects but lack the spatial approach. This new possibility to structurally manage urban social issues is the theory elaborated in the Stiglitz Report, as it may offer a comprehensive means to manage social problems, including social problems in large cities. The study titled „Report by the Commission on the Measurement of Economic Performance and Social Progress” was compiled in 2009 with the leadership of Joseph Stiglitz and the members of the Commission were internationally acknowledged and recognised economists and sociologists. The report was written on the request of the President of the French Republic, Nicholas Sarkozy, in order to examine the main determining factors of the current economic, financial and social crisis, the limitations regarding GDP calculations. The examination was based on the hypothesis that the GDP, as an indicator to measure social and economic processes, is not able to measure social progress. Analyses which justified the document ascertained that the GDP is not the appropriate means to measure the development of social processes (in other words to measure social well-being), and thus new tools of measurement are needed, tools that include the aspects of sustainable development and its three main pillars economic, environmental and social relationships as well. The report clearly verified that the focus must be shifted from production- and economy-oriented measurement to the social well-being of contemporary and future generations. It must be done so that the unfavourable social tensions of the economically-oriented urban planning models, which disregard social aspects, could be managed.

The theoretical significance of the social progress model based on the Stiglitz Report is outstanding as it offers a complex and novel solution to manage current world economic problems, it provides new opportunities for social integration and progress while revitalising economy, but instead of focusing on production it focuses on the well-being of the examined countries and regions. However, the social development model based on the Stiglitz Report is only a theory today, we still lack a complex model which is based on actual empirical facts revealing the connections of economic and social development and social well-being on European, national and worldwide level; there are only analyses that concentrate on certain connections of social well-being, that is we only have partial results. That is why we undertook to carry out a research (in the framework of a 5000-person representative sociological research) that aims to reveal the well-being levels of the different spatial-social groups of the 9 large Hungarian metropolitan regions considering the indicators of the Stiglitz Report. We are going to link the empirically revealed, spatially and socially differentiated well-being indicators to the various social problems and their levels, which are characteristic of the 9 large Hungarian metropolitan regions. This way we will analyse the spatial background of social well-being which depends on structural aspects, the complex determination of urban social problems.

\section{REFERENCES}

Ascher, F. (1995). Métapolis ou l'avenir des villes. Paris: Editions Odile Jacob.

Castells, M. (1972). La question urbanie. Paris: Maspero.

Castells, M., Godard, F. (1974). Monopolville. Paris: L'Entreprise, l'Etat, l'Urbain. Mouton, La Haye.

Le Corbusier (1923). Vers une architecture. Paris: Crès.

Engels, F. (1845). The Condition of the Working Class in England. Oxford University Press.

Enyedi, Gy. (1996). Regionális folyamatok Magyarországon. (Regional Preocesses in Hungary) Budapest: Hilscher Rezső Szociálpolitikai Egyesület.

Enyedi, Gy. (1998). Social Change and Urban Restructuring in Central-Europe. Budapest: Akadémiai Kiadó.

Enyedi, Gy. (2011). The Stages of Urban Growth. In Szirmai, V. (ed.) Urban Sprawl in Europe: Similarities or Differences? (pp. 45-63). Budapest: Aula Kiadó.

Enyedi, Gy. (2012). Városi világ. Budapest: Akadémiai Kiadó. 
Friedmann, J., Wolff, G. (1982). World city formation: an agenda for research and action. International Journal of Urban and Regional Research, 6, 3, 309-344.

Gans, H. J. (1962). The Urban Villagers. Minnsesota State University.

Hall, P. (1996). La ville planétaire. Revue internationale des sciences sociales, 147, 19-31. Howard, E. (1902). Garden Cities of To-Morrow. London.

Kleniewski, N. (2005). Cities and Society. Wiley Blackwell Readers in Sociology.

Park, R. E., Burgess, E. W. - McKenzie, R. D. (1925). The City. Chicago: The University of Chicago Press.

Sassen, S. (1991). Global City: New York, London, Tokyo. Princeton University Press.

Sassen, S. (2007). Urban Sociology in the 21st Century. In Bryant, C.D., Peck, D. L. (eds.), 21 st Century Sociology (pp. 476-486). Sage Publications.

Szirmai, V. (ed.) (2011). Urban Sprawl in Europe: Similarities or Differences? Budapest: Aula Kiadó. 